ACTA UNIVERSITATIS LODZIENSIS

FOLIA LITTERARIA POLONICA 7(45) 2017

http://dx.doi.org/10.18778/1505-9057.45.15

Paulina Pająk*

\title{
Moments of liberty. (Self-)censorship Games in the Essays of Virginia Woolf
}

Pre-Raphaelite profile, subtle facial features, contemplative gaze - that has been the common image of the young Virginia Woolf (1882-1941), the famous modernist writer. This photograph was taken in 1902 by George Charles Beresford and it constitutes one of the most often referenced portraits of the writer.

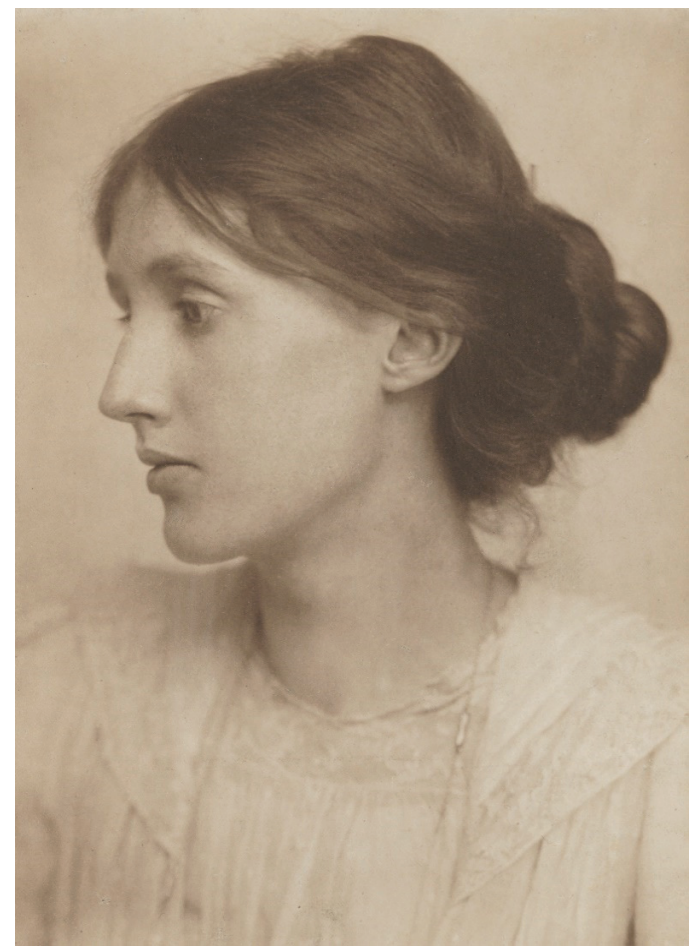

The classic portrait of Virginia Woolf, author: George C. Beresford, July 1902, (source: Virginia Woolf $\odot$ National Portrait Gallery, London).

* Mgr, e-mail: paula.pajak@gmail.com; Institute of English Studies, Faculty of Philology, University of Wroclaw, 50-138 Wroclaw, 22 Kuźnicza street. 
In 1910, there appeared another image which presented her in a slightly different light. It was a photograph of Woolf during the so-called Dreadnought hoax, when six intellectuals took in the British Navy.

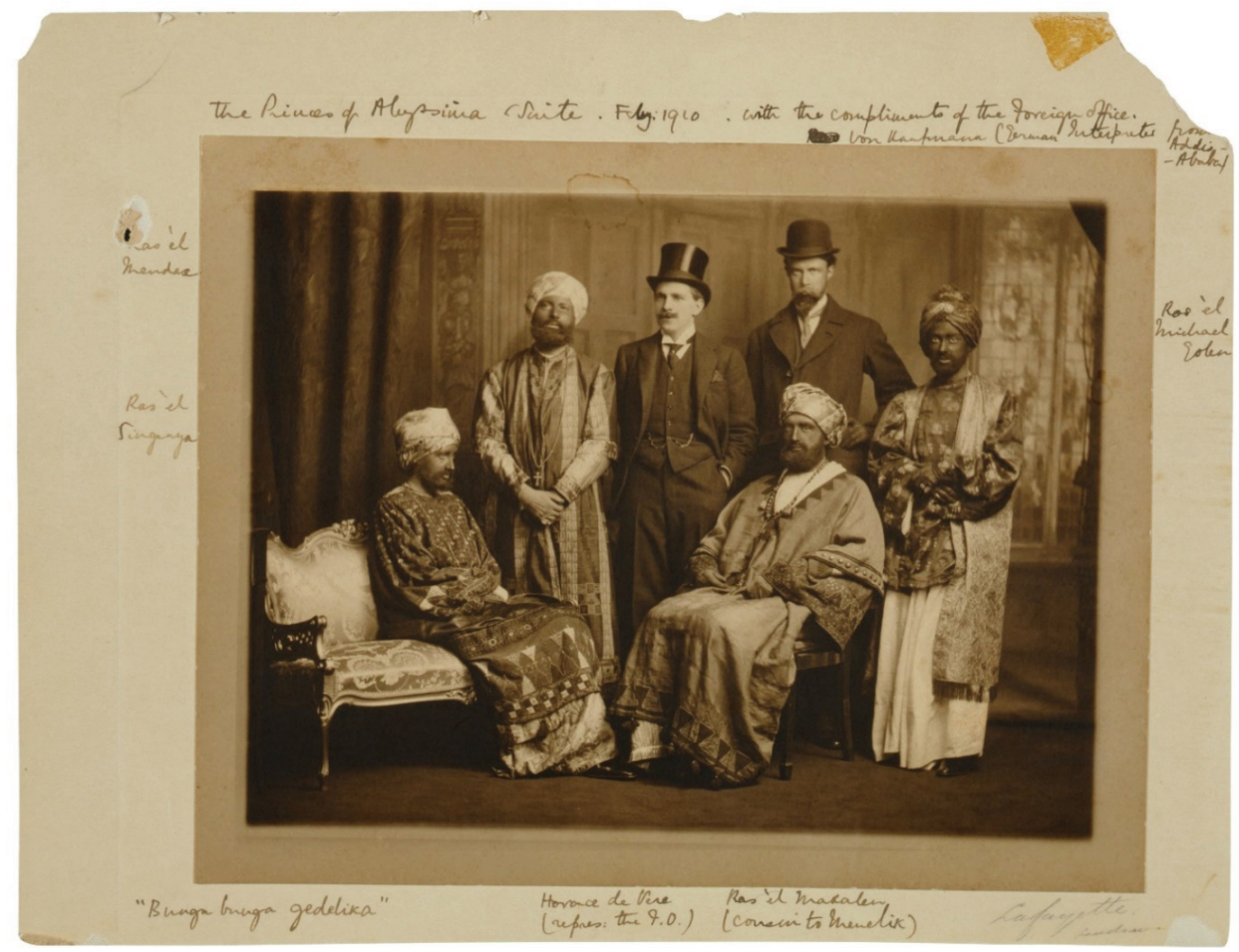

The subversive portrait of Virginia Woolf (seated, on the far left) during the so-called

Dreadnought hoax, author: Lafayette Ltd, 7 February 1910,

(source: The Dreadnought Hoax $\odot$ National Portrait Gallery, London).

The plotters inspected the battleship HMS Dreadnought, which spurred the arms race prior to WWI. Civilians posed as the prince of Abyssinia and his suite, which is why their disguise consisted of blackened faces, fake beards, long robes, and turbans. The fake Abyssinians vocally admired each and every feat of arms technology; they looked up, smacked their lips, and often interjected "bunga, bunga." The honest English considered that as a manifestation of somewhat exotic vessel parametrisation, which is why upon their inspection, the wags stepped off unhindered. On the same day, Horace Cole, the plot's designer, informed the press about the incident. Public opinion effervesced: reactions oscillated from outrage to amusement. ${ }^{1}$

${ }^{1}$ H. Lee, Virginia Woolf, Random House, New York 1999, pp. 278-283 and Q. Bell, Virginia Woolf. Biografia, trans. M. Lavergne, Wydawnictwo Książkowe Twój Styl, Warsaw 2004, pp. 215-221. 
Contemporary critics commonly emphasise the extensive implications of the Dreadnought hoax - they only differ regarding its interpretation. Danell Jones considered it as a pacifist parody, which constituted a symbolic threat to the meticulously prepared Theatre of War:

As embarrassing as the joke might have been, the Admiralty recognized that the real threat was not six sham Abyssinians touring a warship [...]. The real threat was to the navy's image: a single, forty-five minute performance by a group of amateurs was upstaging years of careful and expensive naval theatre. ${ }^{2}$

In the farcical feat Kathy Phillips saw an expression of solidarity with the inhabitants of the colonies and a mockery of racism. ${ }^{3}$ However, Jean E. Kennard seemed to be closer to the plotters' intentions; she interpreted the prank of a group of friends as a subversive camp game mocking militarism and the relations of power. There the scorned and exploited inhabitants of the colonies appeared on Her Majesty's Ship as the Black Majesty and his suite, and the British army paid them the utmost respect. ${ }^{4}$ That anecdote showed that in the times when British artists were fighting for freedom of expression, one could criticise the Empire's colonialism and militarism without having to dread any negative consequences. Of course, provided that the criticism was offered in the form of a prank, and its sting was hidden in ambiguity.

Virginia Woolf was the only woman among the conspirators; in her prose works, she experimented with provocations similarly mocking as the Dreadnought hoax, and just as meticulously concealed. Similarly to other writers who wished to voice their opinions in the contemporary social and political debates, she also felt the petrifying effect of the show-trials of writers and their works accused of obscenity. Woolf's essays showed that she absolutely mastered the poetics of ambiguity, and the ability to entice her readers into a game in which the meaning is the highest prize, though the works were not free of painful self-censorship.

The aim of this article is to present three liberty-focussed streams in Virginia Woolf's essays: women's emancipation, tolerance for people of different psychosexual orientation, and pacifism, as well as the areas of (self-)censorship included therein. Another important topic is the essay as a strategy applied by Woolf to avoid repressive censorship, and an intentional expansion of the limits of liberties important for her.

\footnotetext{
2 D. Jones, “The Dreadnought Hoax And The Theatres Of War", Literature \& History 2013, issue 22.1, pp. 80-94.

${ }^{3}$ K.J. Phillips, Virginia Woolf Against Empire, University of Tennessee Press, Knoxville 1994, pp. $248-250$.

4 J.E. Kennard, "Power and Sexual Ambiguity: The Dreadnought Hoax, The Voyage Out, Mrs Dalloway and Orlando", Journal of Modern Literature 1996, issue 20.2, pp. 149-164.
} 
Her essay works consist of two extensive, over-150-page-long essays A Room of One's Own (Polish ed. 1997) and Three Guineas (Polish ed. 2002) and over 700 short essay forms - a small portion of which were translated into Polish and released in the following collections: Pochyła wieża (1977) and Chwile istnienia: eseje autobiograficzne (2005). In November 2015, Karakter publishing house released a selection of essays prepared by Roma Sendyka and Magda Heydel, one of the best translators of Woolf's works. For the purposes of the analyses presented herein, I used the four-volume issue of Collected essays, which was edited by Leonard Woolf. If possible, the quoted fragments were included based on published Polish translations (if, however, there exist various Polish translations of a text, I selected a translation closest to the original). However, due to the fact that many essays by Woolf have not been translated into Polish yet, the author decided to include her own translations of their fragments (marked in footnotes as "own translation P.P.") - surely not perfect, yet faithful to the original.

\section{In the shadow of repressive censorship}

Why were the matters of intellectual freedom and freedom of speech so important for Virginia Woolf? Her engagement in their defence says a lot both about the writer and the situation in the United Kingdom at that time. The paradox where the more freedoms are guaranteed, the less often we perceive them, was perfectly summarised by Zygmunt Bauman:

"You can say what you wish. This is a free country" We use and hear this expression too often to pause and think of its meaning; we take it as obvious [...] In a sense, freedom is like the air we breathe. We don't ask what this air is, we do not spend time discussing it, arguing about it, thinking of it. That is, unless we are in a crowded, stuffy room and find breathing difficult. ${ }^{5}$

Artists, including modernists, associated the United Kingdom more with Bauman's stuffy room than with a land of freedom, as the ruling politicians willingly called it. As WWI ended, the Defense of the Realm Act was withdrawn, which in reality meant a return to $19^{\text {th }}$-century laws, and the 1857 Obscene Publication Act most of all ${ }^{6}$. On it's basis, each citizen who witnessed the act of selling

${ }^{5}$ Z. Bauman, Wolność, trans. J. Tokarska-Bakir, Znak, Krakow, Fundacja im. Stefana Batorego, Warsaw 1995, p. 5. [English version: Bauman, Zygmunt. Freedom. Milton Keynes: Open University Press].

${ }^{6}$ J. Green, N.J. Karolides, "Hicklin Rule, the", in: eidem, Encyclopedia of Censorship, Facts On File, New York 2005, p. 232. 
the so-called obscene material had the right to file a complaint with a court, which in turn would decide whether to order a search of the book collections of the seller. Thus, it was a form of repressive censorship based on content control of works already published. ${ }^{\text {? }}$

In a monograph entitled British Modernism and Censorship, Celia Marshik described numerous instances of seizures of acclaimed Modernist works by censors. For example, Ulysses by James Joyce was first published in instalments in the American journal The Little Review, and in 1922 it was published in its entirety in France. In the United Kingdom, it was considered as obscene, though censors did not manage to read it, and based their evaluations on the final monologue of Molly Bloom, whom they considered "a vulgar illiterate." Based on an 1876 Customs Consolidation Act, the book could not even be imported to the United Kingdom. Moreover, censors were meticulous about ensuring that Joyce's works did not become British literary mainstream. When the literary scientist F.R. Leavis wanted to discuss Ulysses at the University of Cambridge, his lectures were taken away from him. Therefore, Joyce's ironic commentary on summing up the unifying nature of censorship was not surprising: "a great movement [...] initiated by Puritans, English Imperialists, Irish Republicans, Catholics - what an alliance! I ought to be given the Nobel prize for peace!" 8 Joyce's most renowned book was finally released in the United Kingdom in 1936. Novels by many other authors, including D.H. Lawrence, had to overcome similar obstacles. ${ }^{9}$

In the interwar period, there were also held show-trials of writers, which were the echoes of the trial of Oscar Wilde, though they usually did not lead to such drastic punishments (the writer was convicted of homosexuality and sentenced to two years of hard labour). In that time, it was more common to put on trial novels and not their authors, who were often refused even the right to present their case during the investigations into their outputs. That was the fate of Radclyffe Hall - it was the publisher who was put on trial, regarding her novel entitled Well of Loneliness, which described the romantic relationship between two women. In 1929, the book was banned from circulation in the United Kingdom, yet it became popular in other countries. In Poland, it was published in 1933 as Źródto samotności (Source of Loneliness) with a foreword by Irena Krzywicka, who argued that:

\footnotetext{
${ }^{7}$ J. Green, N.J. Karolides, Obscene Publication Act (1857), ibid., pp. 403-404.

${ }^{8}$ Katherine Mullin quoted Joyce's ironic comment included in a letter to Carlo Linati regarding the fact that the crusade against his book unified antagonised communities. K. Mullin, James Joyce, Sexuality and Social Purity, Cambridge University Press, Cambridge 2003, p. 84.

${ }^{9}$ C. Marshik, British Modernism and Censorship, Cambridge University Press, Cambridge 2006, pp. 157-161.
} 
Love, true love is the greatest moral trial for a heart $[\ldots]$ The novel, confiscated in England, immoral in the common understanding of the word, promotes the sanctity of feelings and all sublime reactions it evokes in human hearts. ${ }^{10}$

Court documents prove that Hall's novel was met with such strong opposition because she presented non-heteronormative characters as likeable persons engaged in their patriotic duty during the Great War. Hall's trial shocked the community of forward-thinking London writers. Virginia Woolf and Edward Morgan Forster issued an open letter in her case, in which they ironically indicated both the hypocrisy of the censors, and the chilling effect resulting from their repressive actions against literary works:

A novelist may not wish to treat any of the subjects mentioned above but the sense that they are prohibited or prohibitable, that there is a taboo-list, will work on him and will make him alert and cautious instead of surrendering himself to his creative impulses. And he will tend to cling to subjects that are officially acceptable, such as murder and adultery, and to shun anything original lest it bring him into forbidden areas. ${ }^{11}$

The letter soon received an answer of sorts: in February 1929, another novel was seized by censors. Funnily enough, it was a book entitled Sleeveless Errand by Norah James, which offered a critical portrait of the moral freedom which arose after $\mathrm{WWI}^{12}$.

\section{Liberty of the essay flâneuse}

Thus, unsurprisingly, in Woolf's works, written in the times when according to the law anyone could become a censor, every now and again there appeared visions of the world as if from Foucault's interpretations of Panopticon by Jeremy Bentham ${ }^{13}$. The "ideal" prison invented by the utilitarian/philosopher was based on the "see without being seen" principle:

Hence the major effect of the Panopticon: to induce in the inmate a state of conscious and permanent visibility that assures the automatic functioning of power. [...] the

${ }^{10}$ I. Krzywicka, Introduction, in: R. Hall, Źródło samotności, Towarzystwo Wydawnicze Rój, Warsaw 1933, p. XI. [English version translated from Polish].

${ }^{11}$ E.M. Forster, V. Woolf, "Letter to the Nation and Athenaeum", in: J. Winning, The Pilgrimage of Dorothy Richardson, University of Wisconsin Press, Madison 2000, pp. 111-112.

${ }^{12}$ C. Marshik, op. cit., pp. 84-85.

${ }^{13}$ Cf. also Z. Bauman, op. cit., pp. 16-20. 
inmate must never know whether he is being looked at at any one moment; but he must be sure that he may always be so. ${ }^{14}$

Therefore, one could assume that the censored panopticism favoured selfcensorship, particularly its public type. According to the division proposed by Philip Cook and Conrad Heilmann, there exist two types of self-censorship: public self-censorship, which applies to the wide range of overt reactions towards institutional censorship, and private self-censorship, which applies to concealing attitudes, on which official censorship has not declared its position or it is not significant. ${ }^{15}$ The spread of repressive censorship in the interwar United Kingdom was the reason why Woolf's works included various traces of public self-censorship, where institutional norms of censorship were, for the purposes of a specific publication, internalised by the subject.

The censorship panopticism is best visible in the essay entitled $A$ Room of One's Own - the flaneuse narrator guides us through a space where the omnipresent censor can hide behind a red curtain or even under the table cloths in the dresser while the traces of his limiting activities remain in the text in the form of ellipses and ambiguity dressed in allusive comments. Then in short essay forms, the process of self-censorship usually remained underneath the surface of a text, hidden under a thick varnish of consecutive versions of an essay. The writer avoided censorship disguising her politically and socially engaged texts in mystifications: that was fostered by the nature of the essay.

In her programme text The Modern Essay, she listed the features of a personal essay most important for her. The first item was a coherent though multifaceted vision enveloping the readers like a curtain "[...] it must be a curtain that shuts us in, not out."16 It had its sources not in escapism but a principle "[...] believed in with conviction or seen with precision and thus compelling words to its shape." ${ }^{17}$ At the same time, according to the author of A Room of One's Own, being true to a principle does not require dogmatism; essayists are protected from its traps thanks to their critical sense of observation and the ability to assume different points of view.

A personal essay is not, of course, possible without, as Woolf put it, "conscious and pure" introduction of the author's personality into the text. Therefore, how does the self or the $I$ emerge in a text? She considered as a model the

\footnotetext{
${ }^{14}$ M. Foucault, Nadzorować i karać. Narodziny więzienia, trans. T. Komendant, Wydawnictwo Fundacja Aletheia, Warsaw 1998, pp. 241-242. [English version: Foucault, Michel. Discipline and Punishment: The Birth of the Prison. New York 1995].

${ }^{15}$ P. Cook, C. Heilmann, "Censorship and two types of self-censorship", LSE Choice Group Working Paper 2002, vol. 6, no. 2, pp. 1-25.

16 V. Woolf, Collected Essays, Hogarth Press, London 1967, vol. 2, p. 51.

${ }^{17}$ Cf. V. Woolf, Collected Essays..., vol. 2, p. 50.
} 
works of Max Beerbohm ${ }^{18}$, who wrote in such a way that "[...] we do not know whether there is any relation between Max the essayist and Mr. Beerbohm the man. We only know that the spirit of personality permeates every word that he writes." 19

As Roma Sendyka emphasised, an analysis of Woolf's essays leads in terms of text personalisation to the following conclusions:

The presence of the first person persona was not desired if it meant an exotic subordination of everything to a single point of view, if it introduced the $I$ devoid of any doubt, perfectly sure of its limits, thus fundamentally non-essayistic..$^{20}$

Therefore, essays by Woolf feature the inclusive form of we, which builds an agreement between the author and common readers, for whom she intended her works. Then, in longer essay forms such as A Room of One's Own or Three Guineas, Woolf constructed female narrators endowed with certain characteristics, and yet different from her - as Wendell V. Harris summarised it: "Woolf's creation of a persona helps create an appreciation of Woolf's mind."21

A Personal essay in an obvious way seemed almost purpose created for the writer's intellectual studies. As Janusz Sławiński wrote:

Actually an essayist's imagination rather feeds on inappropriateness and unfairness. In their wanderings, they choose paths distant from the well-worn motorways of intellectual life (literary, political, academic); they value the wandering itself the most, not the drive towards standard goals. ${ }^{22}$

The essayistic in-between, the programmed fragmented nature marked with the name of drafts, the courage to have doubts, accented by emphasising one's own lack of knowledge - as in the essay entitled Professions for Women, in which she reflected upon who a woman is and her response was "I don't know" - were for Woolf an expression of intellectual freedom. The essayistic nature served

\footnotetext{
${ }^{18}$ Max Beerbohm (1872-1956) - a British essayist, parodist and caricaturist, known for his apt criticism of imperialism presented in the excellent caricatures of typical John Bull or Rudyard Kipling.

${ }^{19}$ V. Woolf, Collected Essays..., vol. 2, p. 45.

${ }^{20}$ R. Sendyka, Nowoczesny esej: studium historycznej świadomości gatunku, Towarzystwo Autorów i Wydawców Prac Naukowych Universitas, Krakow 2006, p. 257. [English version translated from Polish].

${ }^{21}$ W.V. Harris, "Reflections on the Peculiar Status of the Personal Essay", College English 1996, vol. 58, no. 8, p. 942.

22 J. Sławiński, "Ośmiotekst eseistyczny", in: idem, Teksty i teksty, Towarzystwo Autorów i Wydawców Prac Naukowych Universitas, Krakow 2000, p. 254. [English version translated from Polish].
} 
a similar function as the one captured by Teresa Bruś in an analysis of the works by Walter Benjamin ${ }^{23}$ and Wystan Hugh Auden ${ }^{24}$ :

Essaying is a reflective and responsive process of looking back and looking again, observing and seeing with no logical or rhetorical design but with room for being dilatory and not quite familiar with the terrain. ${ }^{25}$

That freedom was reflected in the formula of a journey not free of obstacles, which Woolf used as the framework for A Room of One's Own. But the particular tone of flaneuse is also visible in in her many short essay forms - they possess a clearly kinaesthetic and spatial nature (e.g. Night Walk, Street Haunting: A London Adventure, Rambling Round Evelyn, and Thoughts on Peace in an Air Raid $)^{26}$. A year after Hall's trial, in the acclaimed A Room of One's Own, the writer stated: "Lock up your libraries [...]; but there is not gate, no lock, no bolt, that you can set upon the freedom of my mind." ${ }^{27}$

That freedom of my mind was the goal of the unceasing game between the writer and moral censorship of the epoch, and the similarly sinister (self-)censorship. Thanks to the essayistic experimental space she could study, question, and expand the limits of personal freedom, freedom of expression, and intellectual searching. Thus Woolf restored the once lost women's portion of literary mainstream, though at that time the academic echelon deliberated on the natural intellectual inferiority of women. She demanded the right to love, which led Wilde and Hall in front of the court. She warned about Nazism growing in strength. Therefore, according to the programme assumptions of The Modern Essay, Woolf wrote about the freedoms in which she believed deeply, and she could grasp them with exceptional precision, at the same time without leaving the essayistic state of in-between.

\footnotetext{
${ }^{23}$ Walter Benjamin (1892-1940) - a philosopher, theologian, theoretician of culture, translator, literary critic and essayist.

${ }^{24}$ Wystan Hugh Auden (1907-1973) - a renowned English poet and playwright. In the 1930s, young leftist poets (including: C. Day Lewis, L. MacNeice and S. Spender) remained under such an influence of the poet, that they were collectively referred to as the Auden Generation.

${ }^{25}$ Cf. T. Bruś, "Essaying in Autobiography: Wystan Hugh Auden's and Walter Benjamin's Faces", Biography: An Interdisciplinary Quarterly, 2010, vol. 33.2, p. 334.

${ }^{26}$ In the case of essays translated into Polish, I quote their Polish titles.

${ }^{27}$ V. Woolf, A Room of One's Own \& The Voyage Out, Wordsworth Classics, Ware 2012, p. 81.
} 


\section{Liberty: a women's question}

Woolf's most acclaimed text on the so-called women's question - i.e. raising the issues of women's rights and their situation within the society - was the extensive essay entitled $A$ Room of One's Own. The text has provoked lively debates ever since: it served as an inspiration and was disputed by renowned contemporary female writers, including Doris Lessing (To Room Nineteen) and Alice Walker (In Search of Our Mothers' Gardens: Womanist Prose).

The essay stemmed from two enthusiastically received lectures which Woolf delivered in 1928 for female students of Newnham College and Girton College, the first two female colleges at Cambridge University. The leading theme of both her speeches was Women and Literature, which is why they included scintillating analyses of works by Jane Austen, George Eliot, and Anne, Charlotte and Emily Brontë. According to the assumptions of The Modern Essay, the text was saturated with the writer's personality, and her peculiar sense of humour. Quentin Bell, Woolf's nephew, stressed in her biography that A Room of One's Own reminded him like no other of the manner in which she used to talk with her friends. Regardless of the literary pretext of the lectures, the essay mostly focussed on the matters of women's rights, in particular the right to privacy, financial independence, access to education, and the ability to engage in a professional career.

However, before Woolf presented her views on the women's question, she first constructed a meticulous camouflage: statements regarding the emancipation of women were introduced as if fiction or lies, while misogynistic positions were perversely assigned the brand of truths. This is an example of a safety setting, using which she established the rules of the game with the readers, and which enabled her to fool the censors:

At any rate, when a subject is highly controversial-and any question about sex is that-one cannot hope to tell the truth. One can only show how one came to hold whatever opinion one does hold. One can only give one's audience the chance of drawing their own conclusions as they observe the limitations, the prejudices, the idiosyncrasies of the speaker. Fiction here is likely to contain more truth than fact. Lies will flow from my lips, but there may perhaps be some truth mixed up with them; it is for you to seek out this truth and to decide whether any part of it is worth keeping. If not, you will of course throw the whole of it into the waste-paper basket and forget all about it. ${ }^{28}$

${ }^{28}$ V. Woolf, A Room of One's Own..., pp. 29-30. 
Woolf emphasised the fictional status of both the identity of the narrator of the text and the described universities in a similar perverse manner:

I need not say that what I am about to describe has no existence; Oxbridge is an invention; so is Fernham; 'I' is only a convenient term for somebody who has no real being. ${ }^{29}$

In fact, a careful reading of the essay enables one to notice that the writer endowed the narrator with many of her features, Oxbridge corresponds to Cambridge, while Fernham to its female colleges.

Woolf rebutted the objection which was popular at that time that women's artistic talent cannot match that of men's as the majority of renowned authors were male. She argued that as long as the common woman - note that she entitled the collection of essays The Common Reader twice - does not possess the same rights held by the common man, exceptional women will have considerable difficulty in becoming successful, including in the area of literature. The main two rights were, according to her, one's own room and a modest income enabling one to live independently.

The author of Orlando indicated a range of limitations faced by women who tried to create works of literature. The emphatic illustration of her theses was the fictional character of Judith, Shakespeare's sister, who took her life because, unlike her famous brother, she could not join a theatre troupe or develop her talent at that time, an actress was such an exceptional sight that for Elizabethans she was nothing short of a dancing dog. As the writer stressed, her contemporary times were not free of similar convictions: Samuel Johnson compared female preachers to dancing dogs, while in 1928 that was the common denomination for female composers. That metaphor resurfaced rather unexpectedly in the third chapter of $A$ Room of One's Own, in a poignant satirical portrait of a twisted principle of ownership which lay at the basis of misogyny and colonialism:

[Women] [...] will pass a tombstone or a signpost without feeling an irresistible desire to cut their names on it, as Alf, Bert or Chas. must do in obedience to their instinct, which murmurs if it sees a fine woman go by, or even a dog, Ce chien est à moi. And, of course, it may not be a dog, I thought, remembering Parliament Square, the Sièges Allée and other avenues; it may be a piece of land or a man with curly black hair. ${ }^{30}$

That fragment indicates how Woolf reversed and mocked the misogynous metaphor. The most characteristic feature of A Room of One's Own is the intellectual freedom reflected in the kinaesthetic dimension of the text. The flaneuse narrator

\footnotetext{
${ }^{29}$ Ibid., p. 30.

${ }^{30}$ Ibid., p. 67.
} 
remains in constant motion crossing extensive areas. Soon, however, one sees that her freedom is the freedom of an outcast or an outsider. In Oxbridge she faced new obstacles: she could not stroll on the lawn because that was an area reserved only for students and professors; she could not visit the library without male custody, so it came as no surprise that she passed by the university chapel without even trying to enter, only imagining how she would be thrown out of it as well. Censorship and a lack of women's equal access to education were depicted in a series of closed spaces, which the narrator could not enter.

Even though A Room of One's Own offers the most comprehensive summary of Woolf's feminist postulates, her whole essayistic output is filled with references to the so-called women's question. Among her over 700 short essays only a few do not include observations on the subject. One could identify in those four thematic areas: (1) women's rights, (2) background female characters, (3) mainstream literature written by women, (4) analyses of the output of outstanding writers in terms of representations of women (or a lack of such). The first area is represented by such essays as: Professions for Women, Why? and Memories of a Working Women's Guild. Another device typical of Woolf was to present background female characters, particularly lesser known women professing in science and literature, such as Jane Harrison (1850-1928), an outstanding researcher of ancient Greece (The Intellectual Status of Women), Lucy Baxter (1837 -1902), an art critic (The Countess of Pembroke's Arcadia), and Edith Birkhead (1889-1951), a literary scientist, author of a pioneering work on Gothic literature (Gothic Romance). A particularly interesting device was focalisation used by Woolf in, e.g. an essay entitled Reflections at Sheffield Place, in which the character of the historian Edward Gibbon (1737-1794) was presented from the point of view of three women: Maria, Hester Gibson and Aunt Kitty. An interesting story, from the point of view of contemporary affirmative research into women's writings, was in Woolf's essays the restoration or introduction to the literary mainstream of grand works authored by women - protagonists of such texts as: Women and Fiction, Aurora Leigh, George Eliot, Jane Eyre and Wuthering Heights, Jane Austen and Four Figures. Woolf's reflections on representations of women in the works of renowned prose writers as presented in the essays: Joseph Conrad, The Novels of Thomas Hardy or Henry James also prove extremely valid.

\section{Liberty: love without a name}

A somewhat sidelined area in Woolf's liberty-related considerations was the issue of tolerance for persons of different psycho-sexual orientations. Nonetheless, in A Room of One's Own that issue occupied a significant place: on the one 
hand, due to the growing pressure of moral censorship after Hall's trial, and for personal reasons on the other. Many of her friends from the Bloomsbury group were non-heteronormative, such as Lytton Strechey, the painter Duncan Grant or the economist Maynard Keynes, to nane but a few. For the Cambridge lectures, Woolf came in the company of Vita Sackville-West, a writer, aristocrat, and sapphist, as women who loved other women were commonly referred to at that time. The writer was so fascinated with her friend's personality that she wrote her fictional biography: the novel Orlando, often called the "the most beautiful love letter" in British literature.

In the essay A Room of One's Own, Woolf made a claim in an exceptionally careful manner for the right to love which led Wilde and Hall in front of the court. Fearing censorship, she considered each sentence in such a way for its ambiguity and ironic reading to protect her against any possible accusations. The chilling effect of the writers' trials is indicated in the text through ellipses, i.e. instances of pauses, silence, but also (self-)censorship Woolf administered herself. Several times there appeared a series of questions regarding freedom of expression, and the presence of a censor in the courtroom - in the following fragment it was Chartres Biron, who prohibited the propagation of The Well of Loneliness. The writer thus built an anticipation full of tension:

And, determined to do my duty by her as reader if she would do her duty by me as writer, I turned the page and read ...I am sorry to break off so abruptly. Are there no men present? Do you promise me that behind that red curtain over there the figure of Sir Charles Biron is not concealed? We are all women you assure me? Then I may tell you that the very next words I read were these -'Chloe liked Olivia...' Do not start. Do not blush. Let us admit in the privacy of our own society that these things sometimes happen. Sometimes women do like women. ${ }^{31}$

The famous phrase "Chloe liked Olivia..." is, in fact, nothing more than just a declaration of fondness. And yet when quoted in the context of a man who forbade the selling of Hall's book, it provided impetus for ironic mocking of censorship. Whether due to the fact that the topic of love between people of the same sex was considered as forbidden, one could still write that a woman liked another woman. The hyperbolised reaction of the audience, who upon hearing that simple and insignificant phrase was supposed to rise and blush, was also mocked.

But the mockery of the chilling effect of Hall's trial was also Woolf's attempt at taming her own anxieties regarding the fact of raising the topic of the love without a name. When the writer returned to Chloe and Olivia for the second time, she could not describe their relationship without some self-censorship. The

\footnotetext{
${ }^{31}$ Ibid., pp. $85-86$.
} 
manuscript of the first version of the essay was branded by the author with the following side note:

'Chloe liked Olivia; they shared a-'[the words came at] the bottom of the page; the pages had stuck; while fumbling to open them there flashed into my mind the inevitable policeman; the summons; the order to attend the court; the dreary waiting; the Magistrate coming in with a little bow; the glass of water; the counsel for the prosecution; for the defence; the verdict; this book is called obscene; \& flames rising, perhaps on Tower Hill, as they consumed [that] masses of print paper." 32

Thus, in the final version, one will learn that the women shared not their lives or a house, but a laboratory, while one of them was married. The narration was tempered and limited to a story which could be told without exposing oneself to censorship:

'Chloe liked Olivia. They shared a laboratory together...' I read on and discovered that these two young women were engaged in mincing liver, which is, it seems, a cure for pernicious anaemia; although one of them was married and had-I think I am right in stating-two small children. ${ }^{33}$

The writer one more time referred to the issue of love between women and Hall's trial in the final chapter of the essay:

The truth is, I often like women. I like their unconventionality. I like their completeness. I like their anonymity. I like-but I must not run on in this way. That cupboard there-you say it holds clean table-napkins only; but what if Sir Archibald Bodkin were concealed among them? Let me then adopt a sterner tone. Have I, in the preceding words, conveyed to you sufficiently the warnings and reprobation of mankind? [...] I have indicated what Napoleon once thought of you and what Mussolini thinks now. [...] I have referred to Professor X and given prominence to his statement that women are intellectually, morally and physically inferior to men. ${ }^{34}$

In that instance, the censor reference applied to Archibald Bodkin (18621957), the main prosecutor in Hall's trial, who considered the fact of presenting people of different orientation in a positive way as her main trespass, while for the

\footnotetext{
${ }^{32}$ Cf. S.M. Squier, "Invisible Assistants or Lab Partners? Female Modernism and the Culture(s) of Modern Science", in: Rereading Modernism: New Directions in Feminist Criticism, L. Rado (ed.), Garland Press, New York 1994, p. 310: "A handwritten note by Woolf at the bottom of the page explains the concerns that prevented her from continuing with the passage:"

${ }^{33}$ V. Woolf, A Room of One's Own..., pp. 86-87.

${ }^{34}$ Ibid., p. 106.
} 
book, in which the most graphic scene was one with a kiss, he demanded a ban on its publication. Woolf concluded her essay in a framing device: there returned the figure of the incredible narrator, whose final message to female readers constituted the writer's credo à rebours.

\section{Freedom from dictatorship and war}

No other essay by Woolf was so unfavourably received by the critics as the extensive publication of 1938 entitled Three Guineas. The enthusiastic reaction of the readers somewhat attenuated for the unpleasant experiences associated with the negative comments of people close to her, reflected well in the condescending tone of Quentin Bell: "It is a result of an exceptionally odd mind, and, as I believe, a very odd state of it." " Contemporarily, however, it is considered as one of the most interesting texts by Woolf, in which she spoke, to use Carol Gilligan's term, "in her own voice."

The tripartite epistolary narration of Three Guineas has a polyphonic character. The starting point is the letter of a pacifist vexed by the question "How to prevent war?"; he asks the narrator to help him, also financially, in his cause. The narrator tried to convince him that guaranteeing equal rights for all is a path leading to lasting peace. The menace of war intruded the text from time to time interrupting the reflections with a heart-breaking image: a photograph of destroyed houses and dead people.

Both in terms of narration and the themes, Woolf in Three Guineas abandoned the previously used strategies of evading censorship, and, disregarding her friends' fears, also seldom applied self-censorship. The polyphonic nature of the text was already an expression of opposition towards censorship, which enforced a single acceptable narration. Teresa Winterhalter posited even that:

[...] throughout the essay, Woolf scrutinizes the totalitarian stance of the fascist leader and equates this position with the first-person singular position of a conventional essayist. ${ }^{36}$

Moreover, the writer directly indicated the function of stylistic devices, which previously only signalled censorship to the readers:

${ }^{35}$ Q. Bell, Virginia Woolf. Biografia..., p. 523.

${ }^{36}$ T. Winterhalter, “'What Else Can I Do But Write?' Discursive Disruption and the Ethics of Style in Virginia Woolf's Three Guineas", Hypatia 2003, vol. 18, issue 4, p. 237. 
What then can be the nature of the fear that still makes concealment necessary between educated people and reduces our boasted freedom to a farce?... Again there are three dots; again they represent a gulf-of silence this time, of silence inspired by fear. ${ }^{37}$

Woolf proceeded to find the source of the fear which becomes the reason for self-censorship. And she found it in the gradual limiting of the rights of specific groups of people, mainly women, but also Jews and democrats who were the new women. That was why equality in terms of women's access to education and labour were for her one of the guarantees of peace. As Maggie Humm emphasised: "Those individual liberties, according to Woolf, are completely inter-dependent. Fascism develops in the private patriarchal home." ${ }^{38}$ The previously referenced image of destroyed houses and dead people was juxtaposed with the image of Fascism:

His eyes are glazed; his eyes glare. His body, which is braced in an unnatural position, is tightly cased in a uniform. Upon the breast of that uniform are sewn several medals and other mystic symbols. His hand is upon a sword. He is called in German and Italian Führer or Duce; in our own language Tyrant or Dictator. And behind him lie ruined houses and dead bodies-men, women and children. ${ }^{39}$

The portrait of the dictator referred to the 1935 book entitled Quack, quack by her husband Leonard Woolf - a sagacious study of Fascism from the public perspective. The narration in Three Guineas constantly travels between the private and the public spheres showing their inter-dependency and blurry borders. The only path for women who wish to prevent war is the Outsider Association, while according to Woolf's definition "[...] they would be helped, you will agree, by their position as outsiders, that freedom from unreal loyalties, that freedom from interested motives which are at present assured them by the State [... ${ }^{p 40}$ Therefore, it was an attitude of voluntarily waiving any public honours, which in turn require one to waive one's freedom of expression; it was protection of one's privacy from onlookers, and, finally, it was life in accordance with oneself. The aim of the Outsider Association was, in fact, to demand respect for the dignity of all people: "[...] to the respect in their persons of the great principles of Justice and Equality and Liberty."${ }^{.41}$

\footnotetext{
${ }^{37}$ V. Woolf, A Room of One's Own and Three Guineas, introduction H. Lee, Vintage Random House, London 2001, p. 218.

${ }^{38}$ M. Humm, "Memory, Photography, and Modernism: The 'dead bodies and ruined houses' of Virginia Woolf's Three Guineas", Signs 2003, vol. 28, no. 2, p. 649.

${ }^{39}$ V. Woolf, A Room of One's Own and Three Guineas..., p. 240.

${ }^{40}$ Ibid., p. 211.

${ }^{41}$ Ibid., p. 241.
} 
In Three Guineas one will seldom find the light irony and the excellent parody scenes so typical of the essays of the author of $A$ Room of One's Own, though those certainly include the descriptions of the ceremonial outfits of soldiers, judges, and the members of the academia, suggestive of the Dreadnought hoax. In 1938, when Europe was sinking into darkness, it was increasingly difficult to find laughter, which according to Woolf had the power to save our liberty and humanity:

There is nothing, indeed, so difficult as laughter, but no quality is more valuable. It is a knife that both prunes and trains and gives symmetry and sincerity to our acts and to the spoken and the written word. ${ }^{42}$

\section{Final remarks}

What is surprising in Woolf's essays is the scale and the audacity of her intellectual searches - several decades ago she originally approached topics which have remained controversial ever since. Moreover, she did that in a time of increased repressive censorship and growing totalitarianisms - some had to pay even the highest price for freedom. In fact, Woolf was included in the Sonderfahndungsbuch G.B. list (also referred to as the Black Book), next to prime ministers: Winston Churchill, Neville Chamberlain and Ignacy Paderewski. The persons listed in the Black Book were considered by the Nazis as the enemies of the Third Reich, and were supposed to be arrested first during the planned invasion of the United Kingdom ${ }^{43}$.

Could anyone consider the writer's attention in avoiding any possible consequences of repressive censorship in such circumstances as self-censorship, even its public type? Or maybe as (self-)censorship with a dominant role of that which she managed to communicate regardless of censorship? Doris Lessing was more inclined towards the latter interpretation; when referring to the influence Woolf had on her and other female writers, she emphasised it was mostly about "[...] her existence, bravery, sense of humour, the ability to view women's position without bitterness." 44

\footnotetext{
${ }^{42}$ V. Woolf, The Value of Laughter, in: eadem, The Essays of Virginia Woolf, vol. I, ed. A. McNeillie, Harcourt Brace Jovanovich, San Diego 1986, vol. I, p. 60.

${ }^{43}$ Die Sonderfahndungsliste G.B.: [the Black Book], Imperial War Museum, http://www.iwm.org.uk/collections/item/publication/17293, (accessed on: 15.12.2015).

${ }^{44}$ D. Lessing, Wstęp in: V. Woolf, Siedem szkiców, D. Bradshaw (ed.), trans. M. Lavergne, Wydawnictwo Prószyński i S-ka, Warsaw 2009, p. 13. [English version translated from Polish].
} 


\section{Bibliography (traditional):}

Bauman Zygmunt, Wolność, trans. Joanna Tokarska-Bakir, Znak, Krakow, Fundacja im. Stefana Batorego, Warsaw 1995.

Bell Quentin, Virginia Woolf. Biografia, trans. Maja Lavergne, Wydawnictwo Książkowe Twój Styl, Warsaw 2004.

Bruś Teresa, "Essaying in Autobiography: Wystan Hugh Auden's and Walter Benjamin's Faces”, Biography: An Interdisciplinary Quarterly, 2010, vol. 33.2, pp. 333-349.

Cook Philip, Heilmann Conrad, "Censorship and two types of self-censorship", LSE Choice Group working paper series 2002, vol. 6, no. 2, pp. 1-25.

Forster Edward Morgan, Woolf Virginia, "Letter to the Nation and Athenaeum" in: Joanne Winning, The Pilgrimage of Dorothy Richardson, University of Wisconsin Press, Madison 2000, pp. 111-112.

Foucault Michel, Nadzorować i karać. Narodziny więzienia, trans. Tadeusz Komendant, Wydawnictwo Fundacja Aletheia, Warsaw 1998.

Green Jonathon, Karolides Nicholas James, Encyclopedia of Censorship, Facts On File, New York 2005.

Harris Wendell V., "Reflections on the Peculiar Status of the Personal Essay", College English 1996, vol. 58, no. 8, pp. 934-953.

Humm Maggie, "Memory, Photography, and Modernism: The 'dead bodies and ruined houses' of Virginia Woolf's Three Guineas", Signs 2003, vol. 28, no. 2, pp. 645-663.

Jones Danell, “The Dreadnought Hoax And The Theatres Of War", Literature \& History 2013, issue 22.1, pp. 80-94.

Kennard Jean E., "Power and Sexual Ambiguity: The Dreadnought Hoax, The Voyage Out, Mrs Dalloway and Orlando", Journal of Modern Literature 1996, issue 20.2, pp. 149-164.

Krzywicka Irena, Wstęp, in: Radclyffe Hall, Źródło samotności, Towarzystwo Wydawnicze Rój, Warsaw 1933, pp. V-XI.

Lee Hermione, Virginia Woolf, Random House, New York 1999.

Lessing Doris, Wstęp, in: Virignia Woolf, Siedem szkiców, David Bradshaw (ed.), trans. Maja Lavergne, Wydawnictwo Prószyński i S-ka, Warsaw 2009, pp. 7-14.

Marshik Celia, British Modernism and Censorship, Cambridge University Press, Cambridge 2006.

Mullin Katherine, James Joyce, Sexuality and Social Purity, Cambridge University Press, Cambridge 2003.

Phillips Kathy J., Virginia Woolf Against Empire, University of Tennessee Press, Knoxville 1994.

Sendyka Roma, Nowoczesny esej: studium historycznej świadomości gatunku, Towarzystwo Autorów i Wydawców Prac Naukowych Universitas, Krakow 2006.

Sławiński Janusz, "Ośmiotekst eseistyczny” in: idem, Teksty i teksty, Towarzystwo Autorów i Wydawców Prac Naukowych Universitas, Krakow 2000, pp. 252-258.

Squier Susan Merrill, "Invisible Assistants or Lab Partners? Female Modernism and the Culture(s) of Modern Science", in: Rereading Modernism: New Directions in Feminist Criticism, Lisa Rado (ed.), Garland Press, New York 1994, pp. 299-320.

Winterhalter Teresa, “'What Else Can I Do But Write?' Discursive Disruption and the Ethics of Style in Virginia Woolf's Three Guineas", Hypatia 2003, vol. 18, issue 4, pp. 236-257.

Woolf Virginia, A Room of One's Own \& The Voyage Out, Wordsworth Classics, Ware 2012.

Woolf Virginia, A Room of One's Own and Three Guineas, introduction Hermione Lee, Vintage Random House, London 2001. 
Woolf Virginia, Collected Essays, Leonard Woolf (ed.), Hogarth Press, London 1967, vol. 1-4.

Woolf Virginia, Eseje wybrane, trans. M. Heydel, selection and editing Magda Heydel, Roma

Sendyka, Wydawnictwo Karakter, Krakow 2015.

Woolf Virginia, "The Value of Laughter", in: V. Woolf, The Essays of Virginia Woolf, Andrew McNeillie (ed.), Harcourt Brace Jovanovich, San Diego 1986, vol. I, pp. 58-60.

Woolf Virginia, Trzy gwinee, trans. Ewa Krasińska, Wydawnictwo Sic!, Warsaw 2002.

Woolf Virginia, Własny pokój, trans. Agnieszka Graff, introduction by Izabela Filipiak, Wydawnictwo Sic!, Warsaw 1997.

\section{Paulina Pająk}

\section{Moments of liberty. (Self-)censorship Games in the Essays of Virginia Woolf}

\section{(Summary)}

What is surprising in Virginia Woolf's essays is the scale and the audacity of her intellectual searches - in the time of increased repressive censorship and growing totalitarianisms, she approached the themes of freedom which have remained controversial ever since. The article presents the essayistic nature as a strategy applied by Woolf in her personal essays to avoid censorship, and intentionally expand the limits of freedoms important to her. The author offers an outline of the mechanism of repressive censorship and the chilling effect it worked in the interwar United Kingdom based on the examples of suspensions of outstanding modernist works and show-trials of writers. She presents three areas of study of freedom in Woolf's essays: women's emancipation, tolerance towards non-heteronormative persons, and pacifism, as well as the areas of private and public (self-)censorship which existed therein.

Keywords: Virginia Woolf, liberty, censorship, self-censorship, personal essay, women's emancipation, non-heteronormativity, pacifism. 